\title{
Cropping Systems and Land Use Pattern in Rajshahi Region
}

\author{
M Harun Ar Rashid ${ }^{1 *}$, A B M J Islam², B J Shirazy² and S M Shahidullah²
}

\begin{abstract}
Attempts have been made in this paper to overview the existing cropping patterns, crops diversity and cropping intensity in Rajshahi region. The study was conducted in all the upazilas of four districts of Rajshahi region during 2014-15 using pre-tested semi-structured questionnaires. The most predominating crop in this area was rice where exclusive rice based patterns occupied $40.48 \%$ of NCA. Boro-Fallow-T. Aman was the dominant cropping pattern, occupied 22.83\% of NCA in 27 upazilas out of 32. The second dominant cropping pattern in Rajshahi region was Boro-Fallow-Fallow. It occupied $7.23 \%$ of NCA of the region and existed in 28 upazilas. Wheat-Fallow-T. Aman was the $3^{\text {rd }}$ dominant pattern and practiced in $4.34 \%$ of the NCA in 14 upazilas. The data also revealed that the wheat based patterns stands for $14.7 \%$ of NCA. Mustard-Boro-T. Aman was the $4^{\text {th }}$ dominant cropping pattern. A total of 172 cropping patterns were recognized in this region and the maximum (36) numbers of cropping patterns were identified in Paba upazila nearly followed by Durgapur (35) and Chapainawabganj upazila (34) while the lower numbers of cropping patterns were identified in Charghat (11) followed by Bagha (12) upazila of Rajshahi district. The range of cropping intensity values was recorded 171-253\%. The maximum value was for Badalgachhi of Naogaon district and minimum for Bagha of Rajshahi district. The overall CDI of Rajshahi region was calculated 0.970 and the average cropping intensity at regional level was $218 \%$.
\end{abstract}

Key words: Crop diversity index, cropping pattern, fruit orchard, Barind tract and drought

\section{INTRODUCTION}

In Bangladesh, Rajshahi region especially the Barind Tract is different from other parts of the country due to its undulating topography having compact and low fertile soils. The High Barind Tract, lying in Rajshahi, Chapai Nawabganj and Naogaon districts, is one of the distinct areas of Barind, occupying 160,000 ha, roughly $21 \%$ of the region. The region experienced high temperature with limited soil moisture storage along with low and erratic rainfall (Ali, 2000). The maximum temperature can exceed $40^{\circ} \mathrm{C}$ in May and minimum temperature can fall to $6^{\circ} \mathrm{C}$ in January. Most of the rainfall occurs from June to September and moisture depletion starts from October and in December no residual moisture is available for crop emergence (Idris and Huq, 1987). Land in the High Barind Tract exhibits grey terrace soil, silty loam to silty clay in texture, and is poorly drained, with a 6-8-cm thick plow pan and low organic matter content $(0.8-1.2 \%)$. These situations make the area drought prone along with poor crop productivity. The east and southeast of the Barind is the lower Atrai Basin of Naogaon and Natore district. During the rainy season a vast area of lowland is flooded completely where silts and organic matter from aquatic weeds are deposited on soil and therefore the fertile soils of the specific areas are specially suited to Boro rice cultivation.

Cropping pattern is the yearly sequence, temporal and spatial arrangement of crops in a given land area. Cropping pattern depends on physical, historical, social, economic and institutional factor as well as government

${ }^{1}$ BRRI RS Rajshahi; ${ }^{2}$ Rice Farming Systems Division, BRRI, Gazipur; *Corresponding author's E-mail: harunar73@yahoo.com. 
policies (Agarwall and Kassam, 1976). Rajshahi region is specially suited to lentil, chickpea, tomato and potato. Mango, litchi, palmyra palms and guava are also the major fruit crops in this area. Cropping pattern in a specified region is not static; day by day it is changing. The cropping pattern and the changes depend on a large number of factors like climate, soil type, rainfall, irrigation facilities, agricultural technology and other inputs, marketing and transport facilities and growth of agro industries (Gadge, 2003; Rashid et al., 2005). Recently a number of farmers are converting their crops into mango orchard and continuing cultivation of field crops in the young mango orchard. Like other parts of the country, monsoon T. Aman rice is the major crop in Rajshahi region and backbone of the rural economy. Since 1985, the Barind Multipurpose Development Authority (BMDA) developed a network by installing deep tube wells bringing 162,000 ha land under irrigation across the entire Barind of Bangladesh. Diversified cropping pattern may be an option for the farmers as a coping strategy against risks (Mandal and Bezbaruah, 2013). Typology of different cropping systems is the base for the managers of these systems to intensify production (Shriar, 2000). There is a strong need for judicious and appropriate use of limited resources in case of intervention selection that does not lead to increased mal adaption or inequity in the society over long term. Existing trends of available agricultural lands is most essential requirement for any land use planning related to farming and food security in a sustainable manner. Therefore, an increased understanding of arable land use based on the cropping system is essential for the appropriate intervention in sustainable way. In these context, existing cropping patterns along with their diversity of such complex agricultural region are very crucial for risk minimization and overall productivity improvement. The present study was designed with the following specific objectives to :

- understand the existing cropping patterns scenario in Rajshahi region
- visualize the existing land use pattern at upazila and regional level

- determine the crop diversity and cropping intensity at local and regional level.

\section{METHODOLOGY}

Thirty-two upazilas of Rajshahi, Naogaon, Chapainawabganj and Natore districts under Rajshahi agricultural region were the locale of this study. Data were collected using double stage procedure. At initial stage, data were collected through pre-tested semistructured questionnaire from 32 pre-assigned Sub-Assistant Agriculture Officers (SAAO) of each upazila during February 2016 at upazila level. The SAAOs were purposively preselected by Agriculture Extension Officers (AEO), Additional Agriculture Officer (AAO) and Upazila Agriculture Officer (UAO) or altogether. Prior to data collection, the pretested questionnaire was explained along with proper guidelines to the AEOs or UAOs or both and handed over to them at each Deputy Director's office of the Directorate of Agricultural Extension (DAE) during monthly meeting for the sake of accurate data collection. The scientists of RFS Division collected the filled questionnaires. They also checked and analyzed those to find the inconsistencies of the supplied data before validation workshop. All the inconsistencies among the information were documented. The collected data along with documented inconsistencies were discussed in district level workshop for necessary correction and validation. Second stage of data collection was daylong data validation workshop at district level. The workshop dates were 25 April for Naogaon; 26 April for Natore; 16 August for Rajshahi; and 17 August 2016 for Chapainawabganj. Four field-workers i.e. one SAPPO and three SAAOs experienced and engaged in crop-based data documentation, all officers from all upazilas viz UAOs, AEOs, AAEOs, DD (DAE), DD (Horticulture), DD of Seed Certification Agency, DTO and ADDs, one representative from Agricultural Training 
Institute (ATI) and scientists of BRRI regional station, Kushtia, and Rajshahi participated in the data validation workshop. The number of participants of validation workshop ranged from 56 to 98 in each district. All the participants were divided into three to four groups for data validation. Each group was facilitated by two RFSD scientists to finalize and validate the data and authenticated data were captured. Crop diversity index was calculated by using the following equation described by Kshirsagar et al. (1997).

$$
C D I_{i}=1-\sum_{j=o}^{n}\left(\frac{a_{i j}}{A_{i}}\right)^{2}
$$

Where, $\mathrm{CDI}_{\mathrm{i}}=$ Crop Diversity Index $\mathrm{a}_{\mathrm{ij}}=$ Area planted to the $\mathrm{j}^{\text {th }}$ crop in the $\mathrm{i}^{\text {th }}$ location

$$
\mathrm{A}_{\mathrm{i}}=\text { Total area planted under all crops }
$$

The index is zero for a land area growing only one crop. It approaches unity as the level of diversity increases. Compilation and processing of collected data were done using Micro Soft Excel programme. Descriptive statistics were used to facilitate the presentation of the findings.

\section{RESULTS AND DISCUSSION}

\section{Land use}

Table 1 presents status of agricultural land utilization in the region. The net cropped area of the Rajshahi region is 693,620 ha. Crops occuping the particular land for round the year were considered under annual crops. The major annual crops reported in the region were pineapple, sugarcane, banana, papaya, betel leaf, ginger and turmeric. The annual crops area in different upazilas ranged from 40 to 7,940 ha. The annual crops area accounted only $5.96 \%$ of the net cropped area (NCA) in the region. At a glance the region possesses 10.73\% single cropped area (SCA), $48.38 \%$ double cropped area (DCA), 33.58\% triple cropped area (TCA). The quadruple cropped area QCA also exists as a very negligible portion $(0.67 \%)$ and is limited in only six upazilas viz Badalgachhi, Manda, Mohadevpur and Raninagar of Naogaon district, and Bagha and Mohanpur of Rajshahi district. Compared with DCA and TCA the SCA remained much lower in each and every upazilas. In Rajshahi region, DCA remained higher in Singra upazila of Natore district followed by Godagari upazila of Rajshahi district. Chapainawabganj sadar and Shibganj upazilas are the exceptions where TCA occupied the biggest share of NCA.

\section{Cropping patterns of Rajshahi}

In total 172 cropping patterns were observed in Rajshahi region of which eight cropping patterns with exclusive rice crop covers over $40 \%$ of the NCA. There were 40 cropping patterns with exclusive non-rice crop covering over $7 \%$ of the NCA. Rest of the NCA i.e. about $53 \%$ area is covered by 124 rice - non rice cropping patterns (Appendix 1).

\section{Rice and non-rice crops at a glance}

A wide range of cropping patterns were recognized in the study area and the important feature of the region is that eight patterns were composed of absolutely rice crops. Of all lands used for cultivation, $40.48 \%$ was used only for rice production showing that the farmers are engaged with the traditional rice farming and it is also applicable in Bangladesh (Haque et al., 2012). Boro-Fallow-T. Aman was the most predominant cropping pattern in this area (Table 2). Out of 32 upazilas, the Boro-Fallow-T. Aman cropping pattern remained in 27 upazilas and $22.83 \%$ of the NCA belonged to this pattern. Single Boro was the $2^{\text {nd }}$ dominant pattern, which occupied about $7.23 \%$ of the net cropped area in 28 upazilas. Boro-T. Aus-T. Aman cropping pattern exists in 17 upazilas which was the $3^{\text {rd }}$ dominant copping pattern and occupied 3.65\% of NCA in the region. Single T. Aman was also common in eight upazilas which covered $2.75 \%$ of NCA. Very negligible portion i.e less than $1 \%$ NCA was practiced by Fallow-Aus-T. Aman cropping system in this region.

In the current investigation, 40 cropping patterns were identified that was free from rice. Among thm first 24 have been arranged in descending order in Table 3 . The rest 16 patterns 
Table 1. Land use of different upazilas in Rajshahi region (area in hectare), 2014-15.

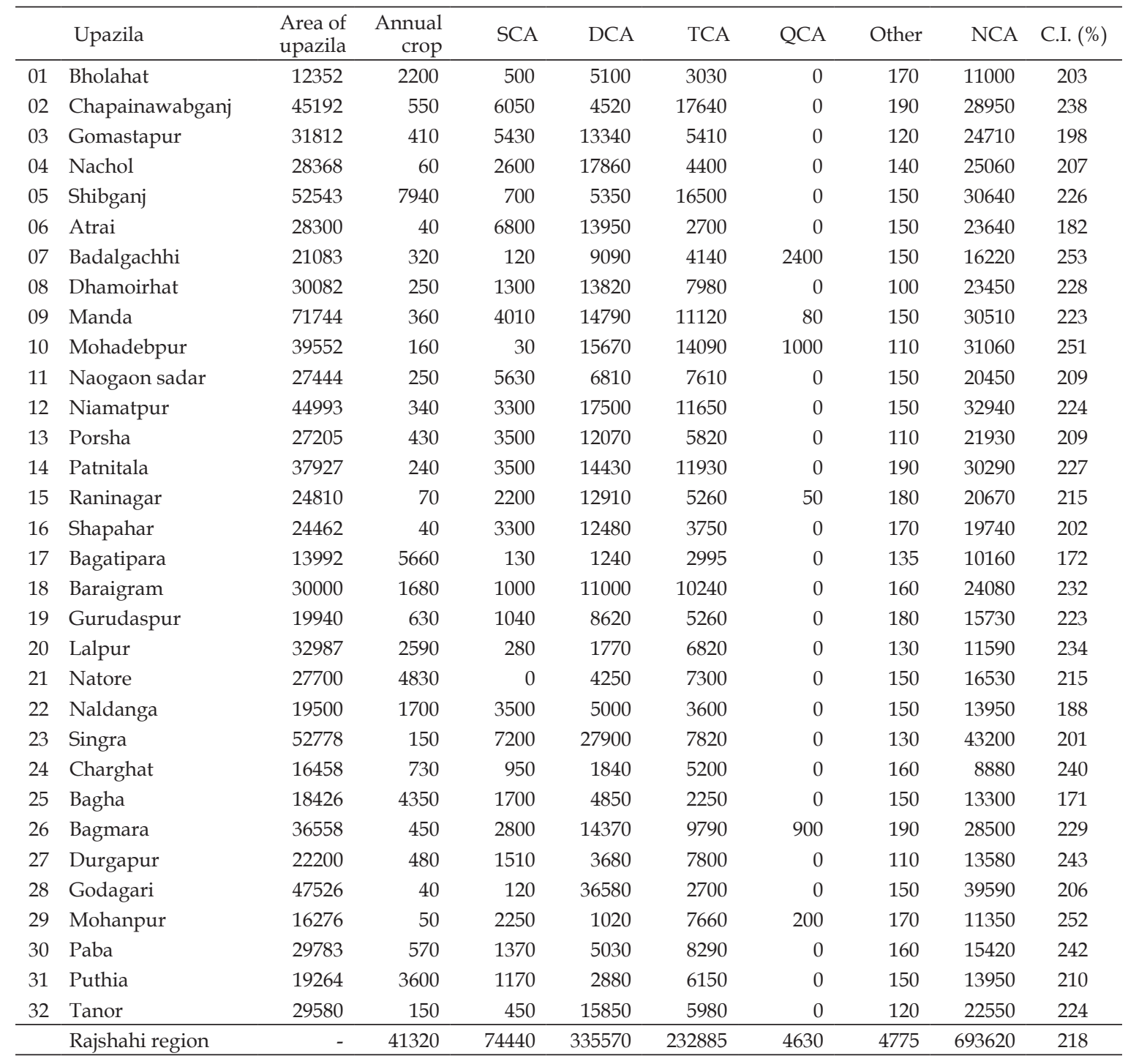

Table 2. Cropping patterns with exclusive rice in Rajshahi region, 2014-15.

\begin{tabular}{llccc}
\hline & Cropping pattern & Area (ha) & \% of NCA & Frequency (no. of upazila) \\
\hline 01 & Boro-Fallow-T. Aman & 158390 & 22.83 & 27 \\
02 & Boro-Fallow-Fallow & 50130 & 7.23 & 28 \\
03 & Boro-Aus-T. Aman & 25290 & 3.65 & 17 \\
04 & Fallow-Fallow-T. Aman & 19100 & 2.75 & 8 \\
05 & Boro-B.Aman & 11650 & 1.68 & 8 \\
06 & Boro-Aus-Fallow & 9500 & 1.37 & 9 \\
07 & Fallow-Aus-T. Aman & 6120 & 0.88 & 3 \\
08 & Boro-Sesbania-T. Aman & 580 & 0.08 & 3 \\
\hline
\end{tabular}


with negligible area coverage arranged in Table 8 with other patterns of different categories. Aggregate of the 40 patterns have had $7.43 \%$ of NCA. In critical comparison it is clear that exclusive rice area is about six folds of exclusive non-rice area. In Rajshahi region, crop diversity is much wider than that of other regions like Sylhet and Chittagong, where exclusive rice area covers 37 folds and 23 folds, respectively, of exclusive non-rice area (Muttaleb et al., 2017; Shahidullah et al., 2017). Appropriate cropping patterns may facilitate maximum possible land utilization as well as efficient use of other scarce resources in a sustainable manner. Diversified cropping pattern may be an option for the farmers as a coping strategy against risks (Mandal and Bezbaruah, 2013). Typology, of different cropping systems, is the base for the managers of these systems to intensify production (Shriar, 2000).

\section{Non-rice cereal crops}

Table 4 presents detailed existing cropping patterns for non-rice cereal crops with area coverage. Forty-four cropping patterns were identified for non-rice cereal cropping systems covering 143,730 ha which represents $20.72 \%$ of NCA in the region. The dominant cropping pattern was the Wheat-Fallow-T. Aman which was practiced on 30,130 ha $(4.34 \%$ of NCA) in 14 upazilas of Rajshahi region. Next cropping pattern under this combination was WheatAus-T. Aman and existed in $2.31 \%$ of the NCA in 14 upazilas. Out of 44 cropping patterns under non-rice cereal systems, 22 patterns were wheat based and the aggregate area under wheat based patterns stands for $16.58 \%$ of NCA in this area. In Bangladesh, there is a vast market of wheat for human consumption and maize seeds for feed industries. Local production of wheat and maize is extremely insignificant to meet up the demand. The situation is increasing our dependency on import causing a great pressure on foreign currency (BBS, 2014). Loam and sandy-loam soil of the comparative dry area is very suitable for maize cultivation. Wheat cultivation with its better yield in this region is specially favoured by long winter season that is normally unavailable in southern parts of the country. Light textured soil with low water-holding capacity as well as less availability of irrigation water are driving forces that discourage the farmers for modern boro cultivation. During the harvesting period of wheat the crop is privileged by clear sun-shine and low humidity. All these are the factors this area is dominated by wheat-based cropping systems (FAO, 1988).

\section{Pulse crops}

Fifty cropping patterns are holding different pulse crops (Table 5). Among them blackgram is covering the largest area whereas pea in the smallest area. Thirteen cropping patterns of blackgram in-together cover 31,720 ha representing $4.57 \%$ of NCA in the Rajshahi region. Mungbean holds the second position in pulse crop cultivation in the region. There are 10 cropping patterns for mungbean covering 24,020 ha $(3.46 \%$ of NCA). In some area of Rajshahi region specifically in Barind tract, Boro cultivation faces some constraints such as scarcity of irrigation water and low-water holding capacity of soil. Moreover, high market price of pulse crops is a driving force for ample cultivation of pulse crops. Among the Rabi crops stress-tolerant mungbean, blackgram, grasspea can easily be grown as relay system and other cropping systems (FAO, 1988).

\section{Oil-seed crops}

Twenty-eight cropping patterns have been arranged in descending order according to area coverage (Table 6). Mustard is the most important one among the oil-seed crops in Rajshahi region. There are 13 cropping had been led by mustard alone which in-together covers 66,050 ha $(9.52 \%$ of NCA). The pattern Mustard-Boro-T. Aman has the highest coverage (3.70\% of the NCA) and was recorded in 17 upazilas out of 32 followed by MustardBoro-Fallow (1.88\% of NCA). Oil is an essential ingredient of human food and also for feed industries. The country is almost dependent on import for oil. Mustard is a very potential crop that can be grown widely in various parts of the country (BBS, 2014). At present, the lion-share 
Table 3. Cropping patterns with exclusive non-rice in Rajshahi region, 2014-15.

\begin{tabular}{|c|c|c|c|c|}
\hline & Cropping pattern & Area (ha) & $\%$ of NCA & Frequency (no. of upazila) \\
\hline 01 & Vegetable-Vegetable-Vegetable & 10715 & 1.54 & 19 \\
\hline 02 & Wheat-Jute-Fallow & 6720 & 0.97 & 6 \\
\hline 03 & Garlic-Jute-Fallow & 4310 & 0.62 & 4 \\
\hline 04 & Vegetab-Vegetab-Fallow & 3500 & 0.54 & 6 \\
\hline 05 & Maize-Fallow-Blackgram & 3350 & 0.50 & 2 \\
\hline 06 & Lentil-Fallow-Fallow (Orchard) & 2780 & 0.43 & 5 \\
\hline 07 & Wheat-Mungbean-Fallow & 2670 & 0.40 & 4 \\
\hline 08 & Potato-Jute-Fallow & 2450 & 0.35 & 3 \\
\hline 09 & Onion-Vegtab-Vegetab & 2370 & 0.34 & 11 \\
\hline 10 & Wheat-Mung-Fallow (Orchard) & 2150 & 0.31 & 3 \\
\hline 11 & Onion-Jute-Fallow & 2010 & 0.29 & 5 \\
\hline 12 & Garlic-Vegetab-Vegetab & 1030 & 0.15 & 10 \\
\hline 13 & Maize-Fallow-Fallow & 1000 & 0.14 & 2 \\
\hline 14 & Potato-Chilli-Fallow & 980 & 0.14 & 6 \\
\hline 15 & Lentil-Vegetab-Vegetab & 760 & 0.11 & 2 \\
\hline 16 & Wht-Sesame-B.gram (Orchard) & 730 & 0.11 & 2 \\
\hline 17 & Chilli-Vegetab-Fallow & 600 & 0.09 & 5 \\
\hline 18 & Wheat-Vegetab-Vegetab & 500 & 0.07 & 2 \\
\hline 19 & Wheat-Jute-Blackgram & 370 & 0.05 & 2 \\
\hline 20 & Wheat-Chilli-Fallow & 290 & 0.04 & 3 \\
\hline 21 & Potato-Maize-Fallow & 270 & 0.04 & 3 \\
\hline 22 & Chilli-Fallow-Fallow & 240 & 0.04 & 3 \\
\hline 23 & S.Potato-Fallow-Fallow & 220 & 0.03 & 4 \\
\hline 24 & Groundnut-Fallow-Fallow & 210 & 0.03 & 2 \\
\hline \multirow[t]{2}{*}{$25-40$} & Other 16 patterns (in Table 8) & 1540 & 0.22 & \\
\hline & Total & 51765 & 7.43 & \\
\hline
\end{tabular}

of mustard cultivation is related to the land for double rice. If technology transfer activities could be strengthen much more area of the aforesaid category will be possible to make room for the mustard crop (FAO, 1988).

\section{Vegetables and spices crops}

A total of 66 cropping patterns were identified in Rajshahi region for vegetables and spices crops. Potato and other vegetables belong to Rabi, Kharif-I and Kharif-II, spices crops viz onion, garlic, coriander, blackcumin and chilli had been included in this list (Table 7). Total area coverage under spices and vegetables is 106,355 ha $(15.27 \%$ of NCA). Among them PotatoBoro-T. Aman is holding the largest coverage with 15,610 ha $(2.31 \%$ of NCA) distributed to 12 upazilas. The $2^{\text {nd }}$ contributing pattern in this category was year-round vegetables, which occupied $1.54 \%$ of NCA with its widest spreading into 19 upazilas.

\section{Sporadic and distinct cropping patterns}

Boro-Aus-Blackgram is an extremely location specific cropping pattern which is limited only in Chapainawabganj sadar upazila with an area of 8,000 ha. Felon-Fallow-T. Aman is another exception which is practiced in Porsha upazila of Naogaon district. This pattern has occupied an area of 6,400 ha of under Barind tract. The third one is the single T. Aman with fruit garden/orchard. The system practiced only in Porsha with an area coverage of 1,000 ha. Rice is cultivated from the time of garden establishment and it is continued up to 7 or 8 years age of fruit trees. The fourth one is Wheat-Aus-Blackgram which is absolutely 
Table 4. Cropping patterns for wheat and maize in Rajshahi region, 2014-15.

\begin{tabular}{|c|c|c|c|c|}
\hline & Cropping pattern & Area (ha) & $\%$ of NCA & Frequency (no. of upazila) \\
\hline 01 & Wheat-Fallow-T. Aman & 30130 & 4.34 & 14 \\
\hline 02 & Wheat-Aus-T. Aman & 16010 & 2.31 & 14 \\
\hline 03 & Wheat-Mungbean-T. Aman & 12570 & 1.81 & 17 \\
\hline 04 & Wheat-Aus-Blackgram & 12030 & 1.73 & 3 \\
\hline 05 & Wheat-Jute-T. Aman & 10270 & 1.48 & 18 \\
\hline 06 & Wheat-Aus-Fallow & 7020 & 1.01 & 8 \\
\hline 07 & Wheat-Jute-Fallow & 6720 & 0.97 & 6 \\
\hline 08 & Potato-Maize-T. Aman & 5350 & 0.77 & 11 \\
\hline 09 & Potato-Maize-Aus & 4000 & 0.58 & 3 \\
\hline 10 & Maize-Fallow-T. Aman & 3780 & 0.54 & 8 \\
\hline 11 & Wheat-F-T. Aman(Orchard) & 3700 & 0.53 & 2 \\
\hline 12 & Maize-Fallow-Blackgram & 3350 & 0.48 & 2 \\
\hline 13 & Wheat-Maize-T. Aman & 2920 & 0.42 & 4 \\
\hline 14 & Lentil-Maize-T. Aman & 2890 & 0.42 & 6 \\
\hline 15 & Wheat-Mungbean-Fallow & 2670 & 0.38 & 4 \\
\hline 16 & Wheat-Mung-Fallow(Orchard) & 2150 & 0.31 & 3 \\
\hline 17 & Wheat-Sesame-T. Aman & 2100 & 0.30 & 7 \\
\hline 18 & Maize-B.Aman & 2000 & 0.29 & 2 \\
\hline 19 & Wheat-Aus-Onion & 1900 & 0.27 & 1 \\
\hline 20 & Maize-Aus-Blackgram & 1300 & 0.19 & 1 \\
\hline 21 & Wheat-Vegetab-T. Aman & 1160 & 0.17 & 6 \\
\hline 22 & Wheat-B.Aman & 1150 & 0.17 & 2 \\
\hline 23 & Onion-Maize-T. Aman & 1050 & 0.15 & 3 \\
\hline 24 & Maize-Fallow-Fallow & 1000 & 0.14 & 2 \\
\hline 25 & Wht-Sesame-B.gram(Orchard) & 730 & 0.11 & 2 \\
\hline 26 & Potato-Maize-Aus-Vegetab & 700 & 0.10 & 1 \\
\hline 27 & Wheat-Vegetab-Vegetab & 500 & 0.07 & 2 \\
\hline 28 & Maize-Aus-T. Aman & 440 & 0.06 & 3 \\
\hline 29 & Vegetab-Maize-Fallow & 430 & 0.06 & 1 \\
\hline 30 & Maize-Maize-Fallow & 400 & 0.06 & 1 \\
\hline 31 & Onion-Maize-Fallow & 400 & 0.06 & 1 \\
\hline 32 & Wheat-Jute-Blackgram & 370 & 0.05 & 2 \\
\hline 33 & Boro-Maize-Blackgram & 350 & 0.05 & 1 \\
\hline 34 & Boro-Maize-Fallow & 350 & 0.05 & 1 \\
\hline 35 & Maize-Aus-Fallow & 300 & 0.04 & 1 \\
\hline 36 & Potato-Maize-Vegetab & 300 & 0.04 & 1 \\
\hline 37 & Wheat-Chilli-Fallow & 290 & 0.04 & 3 \\
\hline 38 & Potato-Maize-Fallow & 270 & 0.04 & 3 \\
\hline \multirow[t]{2}{*}{$39-44$} & Other six patterns (table 8) & 680 & 0.10 & - \\
\hline & Total maize and wheat & 143730 & 20.72 & \\
\hline
\end{tabular}

practiced in Chapainawabganj district with an area coverage of 12,030 ha. This pattern, as far known, does not exist anywhere in Bangladesh out of the district. Three upazilas of the district viz Shibiganj, sadar and Bholahat are holding 10,000 ha, 1,400 ha and 630 ha of land, respectively, for the cropping pattern.

\section{Rare cropping patterns}

Rajshahi region is a diversified cropping zone. Forty-four rare cropping patterns with negligible area coverage in the specific one or two upazilas had been identified in this region (Table 8 ). However, total area coverage of these patterns was only $0.54 \%$ of NCA. Out 
Table 5. Cropping patterns of pulses crops in Rajshahi region, 2014-15.

\begin{tabular}{|c|c|c|c|c|}
\hline & Cropping pattern & Area (ha) & $\%$ of NCA & Frequency (no. of upazila) \\
\hline 01 & Wheat-Mungbean-T. Aman & 12570 & 1.81 & 17 \\
\hline 02 & Wheat-Aus-Blackgram & 12030 & 1.73 & 3 \\
\hline 03 & Boro-Aus-Blackgram & 8000 & 1.15 & 1 \\
\hline 04 & Felon-Fallow-T. Aman & 6400 & 0.92 & 1 \\
\hline 05 & Lentil-Fallow-T. Aman & 4370 & 0.63 & 6 \\
\hline 06 & Maize-Fallow-Blackgram & 3350 & 0.48 & 2 \\
\hline 07 & Lentil-Maize-T. Aman & 2890 & 0.42 & 6 \\
\hline 08 & Lentil-Fallow-Fallow(Orchard) & 2780 & 0.40 & 5 \\
\hline 09 & Wheat-Mungbean-Fallow & 2670 & 0.38 & 4 \\
\hline 10 & Garlic-Mungbean-T. Aman & 2500 & 0.36 & 2 \\
\hline 11 & Lentil-Jute-T. Aman & 2410 & 0.35 & 6 \\
\hline 12 & Wheat-Mung-Fallow(Orchard) & 2150 & 0.31 & 3 \\
\hline 13 & Chickpea-Fallow-T. Aman & 2110 & 0.30 & 5 \\
\hline 14 & Boro-Fallow-Blackgram & 2000 & 0.29 & 4 \\
\hline 15 & Grasspea-Boro-Aus & 1800 & 0.26 & 1 \\
\hline 16 & Lentil-Mungbean-T. Aman & 1750 & 0.25 & 5 \\
\hline 17 & Mustard-Mungbean-T. Aman & 1700 & 0.25 & 2 \\
\hline 18 & Mustard-Aus-Blackgram & 1500 & 0.22 & 1 \\
\hline 19 & Vegetab-Aus-Blackgram & 1500 & 0.22 & 1 \\
\hline 20 & Grasspea-B.Aman & 1380 & 0.20 & 3 \\
\hline 21 & Maize-Aus-Blackgram & 1300 & 0.19 & 1 \\
\hline 22 & Onion-Aus-Blackgram & 870 & 0.13 & 2 \\
\hline 23 & Lentil-Vegetab-Vegetab & 760 & 0.11 & 2 \\
\hline 24 & Wht-Sesame-B.gram(Orchard) & 730 & 0.11 & 2 \\
\hline 25 & Lentil-Aus-T. Aman & 710 & 0.10 & 3 \\
\hline 26 & Lentil-Sesame-T. Aman & 710 & 0.10 & 3 \\
\hline 27 & Lentil-Aus-Fallow & 620 & 0.09 & 2 \\
\hline 28 & Mungbean-Aus-T. Aman & 600 & 0.09 & 1 \\
\hline 29 & Wheat-Jute-Blackgram & 370 & 0.05 & 2 \\
\hline 30 & Boro-Maize-Blackgram & 350 & 0.05 & 1 \\
\hline 31 & Grasspea-Fallow-T. Aman & 350 & 0.05 & 4 \\
\hline 32 & Lentil-Sesame-Fallow & 300 & 0.04 & 1 \\
\hline 33 & Grasspea-Aus-Blackgram & 250 & 0.04 & 1 \\
\hline \multirow[t]{2}{*}{$34-50$} & Other 17 patterns (Table 8) & 1410 & 0.20 & \\
\hline & Total pulse crop & 85190 & 12.23 & \\
\hline
\end{tabular}

of 43 patterns, each of nine patterns namely Groundnut-Aus-Fallow, Lentil-B. Aman, Lentil-Jute-Fallow, Lentil-Jute-Fallow, LentilJute-Fallow, Vegetab-Onion-Jute-T. Aman, Wheat-Fallow-Fallow, Wheat-Jute-Vegetab and Wheat-Sesame-Fallow occupied the same areas of 200 ha land in different nine upazilas of this region.

\section{Most dominant cropping pattern}

Boro-Fallow-T. Aman was the major cropping pattern in Rajshahi region and the pattern was common in 27 upazilas which occupied $22.83 \%$ of NCA in the region (Table 9). The highest area coverage under Boro-Fallow-T. Aman pattern was found in Singra (19,100 ha) upazila of Natore district followed by Dhamoirhat (13,000 ha), Mohadebpur (12,800 ha), Patnitala $(12,600 \mathrm{ha})$ and Raninagar (12,600 ha) upazilas of Naogaon district indicated that Naogaon district was the dominant rice growing zone. Although the higher area coverage was found in Singra upazila but the percent of upazila net cropped area with this pattern remained higher in Raninagar (61\%) upazila followed by Dhamoirhat upazila (56\%) of Naogaon district. 
Table 6. Cropping patterns of oil-seed crops in Rajshahi region, 2014-15.

\begin{tabular}{|c|c|c|c|c|}
\hline & Cropping pattern & Area (ha) & $\%$ of NCA & Frequency (no. of upazila) \\
\hline 01 & Mustard-Boro-T. Aman & 25650 & 3.70 & 17 \\
\hline 02 & Mustard-Boro-Fallow & 13050 & 1.88 & 9 \\
\hline 03 & Mustard-Boro-Aus & 10200 & 1.47 & 8 \\
\hline 04 & Mustard-Fallow-T. Aman & 6000 & 0.87 & 7 \\
\hline 05 & Mustard-Aus-T. Aman & 3800 & 0.55 & 4 \\
\hline 06 & Wheat-Sesame-T. Aman & 2100 & 0.30 & 7 \\
\hline 07 & Mustard-Boro-B.Aman & 1800 & 0.26 & 1 \\
\hline 08 & Mustard-Boro-Aus-T. Aman & 1700 & 0.25 & 4 \\
\hline 09 & Mustard-Mungbean-T. Aman & 1700 & 0.25 & 2 \\
\hline 10 & Mustard-Aus-Blackgram & 1500 & 0.22 & 1 \\
\hline 11 & Wht-Sesame-Blackgram (Orchard) & 730 & 0.11 & 2 \\
\hline 12 & Lentil-Sesame-T. Aman & 710 & 0.10 & 3 \\
\hline 13 & Lentil-Sesame-Fallow & 300 & 0.04 & 1 \\
\hline 14 & Onion-Sesame-Fallow & 280 & 0.04 & 1 \\
\hline 15 & Mustard-Aus-Fallow & 250 & 0.04 & 1 \\
\hline 16 & Groundnut-Fallow-Fallow & 210 & 0.03 & 2 \\
\hline \multirow[t]{2}{*}{$17-28$} & Other 12 patterns (in Table 8) & 1120 & 0.16 & - \\
\hline & Total oil-seed crop & 71100 & 10.21 & \\
\hline
\end{tabular}

The lowest area coverage as well as percent of upazila net cropped area under Boro-Fallow-T. Aman cropping pattern in Rajshahi region existed in Charghat upazila decreasingly followed by Paba upazila of Rajshahi district. In the country-wide compilation of data it was observed that Boro-F-T. Aman was the most dominant cropping pattern in Bangladesh covering 2.31 million ha $(27 \%$ of NCA in the country) with its distribution in 426 upazilas of 63 districts (Nasim et al., 2017).

\section{Second dominant cropping pattern}

The second most dominant cropping pattern in Rajshahi region was Boro-Fallow-Fallow. It occupied 7.23 of NCA of the region and existed in 28 upazilas (Table 10). The area coverage under single Boro remained higher in Singra upazila of Natore holds the largest area 7,200 ha which is equivalent to $14.36 \%$ of the total area for the pattern in the region. Naldanga upazila of Natore district stands fifth position for area coverage (3,500 ha), however, this upazila had allocated the biggest share i.e. $28.57 \%$ of its NCA. The lowest area (50 ha) coverage under Boro-Fallow-Fallow cropping pattern has been identified in Chapainawabganj sadar and Charghat upazila of Rajshahi district. Out of nine upazilas of Rajshahi district, only Bagmara upazila holds considerable area 2,800 ha (9.98\% of upazila NCA) under this single Boro cropping pattern. This pattern is frequent and concurrently experienced by early flashflood in April and cold injury at reproductive stage. Diversified cropping pattern may be resort for the farmer as a coping strategy with flood related risk (Mandal and Bezbaruah, 2013) but scope of diversification is limited due to environmental and climatic condition (FAO, 1988). In the country-wide compilation of data it was observed that the single Boro was the $2^{\text {nd }}$ dominant cropping pattern in Bangladesh covering 1.14 million ha $(13 \%$ of NCA in the country) with its distribution in 342 upazilas of 59 districts (Nasim et al., 2017).

\section{Third dominant cropping pattern}

Third dominant cropping Wheat-Fallow-T. Aman occupied the 30,130 ha of land and represented $4.34 \%$ of NCA in Rajshahi region (Table 11). This pattern distributed over 14 upazilas where Shapahar ranked top position covering 7,500 ha of land. Godagari and Nachol ranked the $2^{\text {nd }}$ and $3^{\text {rd }}$ position under WheatFallow-T. Aman cropping pattern covering 6,000 ha and 5,000 ha of land, respectively. 
Table 7. Cropping patterns for vegetables and spices crops in Rajshahi region, 2014-15.

\begin{tabular}{|c|c|c|c|c|}
\hline & Cropping pattern & Area (ha) & $\%$ of NCA & Frequency (no. of upazila) \\
\hline 01 & Potato-Boro-T. Aman & 15610 & 2.25 & 12 \\
\hline 02 & Vegetable-Vegetable-Vegetable & 10715 & 1.54 & 19 \\
\hline 03 & Potato-Boro-Aus & 7200 & 1.04 & 4 \\
\hline 04 & Garlic-B.Aman & 6200 & 0.89 & 3 \\
\hline 05 & Potato-Boro-Fallow & 5800 & 0.84 & 2 \\
\hline 06 & Onion-Aus-Fallow & 4450 & 0.64 & 5 \\
\hline 07 & Garlic-Jute-Fallow & 4310 & 0.62 & 4 \\
\hline 08 & Potato-Fallow-T. Aman & 4050 & 0.58 & 6 \\
\hline 09 & Vegetab-Aus-Fallow & 3680 & 0.53 & 4 \\
\hline 10 & Vegetab-Vegetab-T. Aman & 3550 & 0.51 & 7 \\
\hline 11 & Vegetab-Vegetab-Fallow & 3500 & 0.50 & 6 \\
\hline 12 & Onion-Jute-T. Aman & 2750 & 0.40 & 6 \\
\hline 13 & Chilli-Aus-T. Aman & 2600 & 0.37 & 2 \\
\hline 14 & Potato-Aus-T. Aman & 2600 & 0.37 & 5 \\
\hline 15 & Potato-Jute-Fallow & 2450 & 0.35 & 3 \\
\hline 16 & Onion-Vegtab-Vegetab & 2370 & 0.34 & 11 \\
\hline 17 & Garlic-Jute-T. Aman & 2320 & 0.33 & 8 \\
\hline 18 & Onion-Jute-Fallow & 2010 & 0.29 & 5 \\
\hline 19 & Potato-Jute-T. Aman & 1980 & 0.29 & 5 \\
\hline 20 & Onion-Fallow-T. Aman & 1840 & 0.27 & 7 \\
\hline 21 & Vegetab-Aus-T. Aman & 1640 & 0.24 & 5 \\
\hline 22 & Vegetab-Fallow-T. Aman & 1550 & 0.22 & 4 \\
\hline 23 & Potato-Aus-Fallow & 1300 & 0.19 & 4 \\
\hline 24 & Garlic-Vegetab-Vegetab & 1030 & 0.15 & 10 \\
\hline 25 & Potato-Chilli-Fallow & 980 & 0.14 & 6 \\
\hline 26 & Lentil-Vegetab-Vegetab & 760 & 0.11 & 2 \\
\hline 27 & Potato-Vegetab-T. Aman & 700 & 0.10 & 2 \\
\hline 28 & Chilli-Fallow-T. Aman & 670 & 0.10 & 6 \\
\hline 29 & Garlic-Aus-Fallow & 660 & 0.10 & 5 \\
\hline 30 & Boro-Vegetab(Float/Norm) & 630 & 0.09 & 2 \\
\hline 31 & Chilli-Vegetab-Fallow & 600 & 0.09 & 5 \\
\hline 32 & Wheat-Vegetab-Vegetab & 500 & 0.07 & 2 \\
\hline 33 & Garlic-Aus-T. Aman & 490 & 0.07 & 3 \\
\hline 34 & Garlic-Fallow-T. Aman & 410 & 0.06 & 4 \\
\hline 35 & Chilli-Aus-Fallow & 400 & 0.06 & 3 \\
\hline 36 & Garlic+Muskmelon-B.Aman & 320 & 0.05 & 2 \\
\hline 37 & Garlic+W.Melon-B.Aman & 320 & 0.05 & 2 \\
\hline 38 & Vegetab-Boro-T. Aman & 300 & 0.04 & 2 \\
\hline 39 & Wheat-Chilli-Fallow & 290 & 0.04 & 3 \\
\hline 40 & Potato-Maize-Fallow & 270 & 0.04 & 3 \\
\hline 41 & Vegetab-Jute-T. Aman & 270 & 0.04 & 2 \\
\hline 42 & Potato-Boro-Aus-T. Aman & 230 & 0.03 & 2 \\
\hline 43 & Coriander-Fallow-Fallow & 220 & 0.03 & 2 \\
\hline 44 & Chilli-Fallow-Fallow & 240 & 0.03 & 3 \\
\hline 45 & Chilli-Vegetab-T. Aman & 210 & 0.03 & 2 \\
\hline $46-66$ & Other 21 patterns (in Table 8) & 1380 & 0.20 & - \\
\hline & Total veg. and spices crops & 106355 & 15.27 & \\
\hline
\end{tabular}


Table 8. Rare cropping patterns covering non-significant area in Rajshahi region, 2014-15.

\begin{tabular}{|c|c|c|c|c|c|}
\hline & Cropping pattern & Area (ha) & $\%$ of NCA & Frequency & Upazila \\
\hline 01 & Groundnut- Aus-Fallow & 200 & 0.03 & 1 & Lalpur \\
\hline 02 & Lentil-B.Aman & 200 & 0.03 & 1 & Gurudaspur \\
\hline 03 & Lentil-Jute-Fallow & 200 & 0.03 & 1 & Nachol \\
\hline 04 & Lentil-Vegetab-T. Aman & 200 & 0.03 & 1 & Nachol \\
\hline 05 & Lentil-Jute-Fallow & 200 & 0.03 & 1 & Gurudaspur \\
\hline 06 & Vegetab-Onion-Jute-T. Aman & 200 & 0.03 & 1 & Mohanpur \\
\hline 07 & Wheat-Fallow-Fallow & 200 & 0.03 & 1 & Bagatipara \\
\hline 08 & Wheat-Jute-Vegetab & 200 & 0.03 & 1 & Naogaon sadar \\
\hline 09 & Wheat-Sesame-Fallow & 200 & 0.03 & 1 & Bagatipara \\
\hline 10 & Grasspea-Jute-T. Aman & 190 & 0.03 & 2 & Lalpur+Bagatipara \\
\hline 11 & Fallow-Fallow-Blackgram & 170 & 0.02 & 3 & Manda+Gurudaspur+Paba \\
\hline 12 & Chilli-Jute-T. Aman & 170 & 0.02 & 2 & Dhamoirhat+Shibganj \\
\hline 13 & Grasspea-Boro-Fallow & 150 & 0.02 & 1 & Paba \\
\hline 14 & Mustard-Fallow-Fallow & 150 & 0.02 & 1 & Paba \\
\hline 15 & Garlic-Fallow-Fallow & 120 & 0.02 & 1 & Lalpur \\
\hline 16 & Potato-Sesame-Aus & 120 & 0.02 & 1 & Bagmara \\
\hline 17 & Groundnut-Fallow-T. Aman & 100 & 0.01 & 1 & Atrai \\
\hline 18 & Boro-Sesbania-Fallow & 80 & 0.01 & 1 & Godagari \\
\hline 19 & Boro-Vegetab-T. Aman & 70 & 0.01 & 1 & Paba \\
\hline 20 & Coriander-Fallow-T. Aman & 50 & 0.01 & 2 & Chapai sadar +Gomastapur \\
\hline 21 & Grasspea-Mungbean-T. Aman & 50 & 0.01 & 1 & Lalpur \\
\hline 22 & Mustard-Maize-T. Aman & 50 & 0.01 & 1 & Manda \\
\hline 23 & Grasspea-Sesame-T. Aman & 40 & 0.01 & 1 & Lalpur \\
\hline 24 & Pea-Aus-Vegetab & 40 & 0.01 & 2 & Paba+Nachol \\
\hline 25 & Pea-Fallow-T. Aman & 40 & 0.01 & 2 & Chapai sadar +Gomastapur \\
\hline 26 & Blackgram-Jute-Fallow & 30 & 0.00 & 1 & Manda \\
\hline 27 & Coriander-Vegetab-Fallow & 30 & 0.00 & 1 & Naogaon sadar \\
\hline 28 & Potato-Sesame-T. Aman & 30 & 0.00 & 1 & Durgapur \\
\hline 29 & Blackcumin-Jute-T. Aman & 20 & 0.00 & 1 & Gurudaspur \\
\hline 30 & Chickpea-Aus-T. Aman & 20 & 0.00 & 1 & Paba \\
\hline 31 & Chilli-Jute-Fallow & 20 & 0.00 & 1 & Badalgachhi \\
\hline 32 & Coriander-B.Aman & 20 & 0.00 & 1 & Gurudaspur \\
\hline 33 & Coriander-Jute-T. Aman & 20 & 0.00 & 2 & Gurudaspur+Dhamoirhat \\
\hline 34 & Grasspea-Jute-Fallow & 20 & 0.00 & 1 & Manda \\
\hline 35 & Maize-Jute-T. Aman & 20 & 0.00 & 1 & Durgapur \\
\hline 36 & Pea-Jute-Fallow & 20 & 0.00 & 1 & Lalpur \\
\hline 37 & Potato-Mungbean-T. Aman & 20 & 0.00 & 2 & Durgapur+Chapai sadar \\
\hline 38 & Coriander-Sesame-T. Aman & 10 & 0.00 & 1 & Mohadebpur \\
\hline 39 & Grasspea-Fallow-Fallow & 10 & 0.00 & 1 & Gomastapur \\
\hline 40 & Maize-Vegetab-T. Aman & 10 & 0.00 & 1 & Durgapur \\
\hline 41 & Mungbean-Fallow-T. Aman & 10 & 0.00 & 1 & Charghat \\
\hline 42 & Potato-Groundnut & 10 & 0.00 & 1 & Raninagar \\
\hline 43 & Potato-Groundnut-T. Aman & 10 & 0.00 & 1 & Raninagar \\
\hline \multirow[t]{2}{*}{44} & Vegetab-Fallow-Fallow & 10 & 0.00 & 1 & Durgapur \\
\hline & Total & 3730 & 0.54 & & \\
\hline
\end{tabular}


Table 9. Distribution of the most dominant Boro-Fallow-T. Aman cropping patterns in Rajshahi region, 2014-15.

\begin{tabular}{|c|c|c|c|c|}
\hline & Upazila & Area (ha) & $\%$ of upazila NCA & $\%$ of the pattern in region \\
\hline 01 & Singra & 19100 & 45.00 & 12.06 \\
\hline 02 & Dhamoirhat & 13000 & 56.00 & 8.21 \\
\hline 03 & Mohadebpur & 12800 & 41.00 & 8.08 \\
\hline 04 & Patnitala & 12600 & 42.00 & 7.96 \\
\hline 05 & Raninagar & 12600 & 61.00 & 7.96 \\
\hline 06 & Niamatpur & 12000 & 37.00 & 7.58 \\
\hline 07 & Godagari & 12000 & 30.00 & 7.58 \\
\hline 08 & Badalgachhi & 8500 & 53.00 & 5.37 \\
\hline 09 & Tanor & 7400 & 33.00 & 4.67 \\
\hline 10 & Manda & 6500 & 22.00 & 4.10 \\
\hline 11 & Naogan Sodar & 6000 & 30.00 & 3.79 \\
\hline 12 & Gomastapur & 5800 & 23.90 & 3.66 \\
\hline 13 & Atrai & 5300 & 22.50 & 3.35 \\
\hline 14 & Nachol & 5000 & 20.00 & 3.16 \\
\hline 15 & Porsha & 4100 & 19.00 & 2.59 \\
\hline 16 & Naldanga & 3500 & 29.00 & 2.21 \\
\hline 17 & Shapahar & 3000 & 15.00 & 1.89 \\
\hline 18 & Bholahat & 1900 & 22.00 & 1.20 \\
\hline 19 & Natore & 1700 & 15.00 & 1.07 \\
\hline 20 & Puthia & 1700 & 17.00 & 1.07 \\
\hline 21 & Chapainawabganj & 1000 & 3.50 & 0.63 \\
\hline 22 & Durgapur & 1000 & 7.60 & 0.63 \\
\hline 23 & Baraigram & 700 & 3.10 & 0.44 \\
\hline 24 & Bagatipara & 490 & 10.90 & 0.31 \\
\hline 25 & Shibganj & 400 & 1.80 & 0.25 \\
\hline 26 & Paba & 200 & 1.40 & 0.13 \\
\hline \multirow[t]{2}{*}{27} & Charghat & 100 & 1.20 & 0.06 \\
\hline & Rajshahi region & 158390 & 22.83 & 100.00 \\
\hline
\end{tabular}

The lowest area coverage (100 ha) under this cropping pattern existed in Chapai sadar upazila decreasingly followed by Porsha and Raninagar upazila where each of two upazila held only 150 ha of land.

\section{Fourth dominant cropping pattern}

The fourth dominant cropping pattern in Rajshahi region was Mustard-Boro-T. Aman existed in 17 upazilas representing 3.70\% share of NCA (Table 12). The area coverage under this pattern remained higher (4,700 ha each) in Patnitala and Manda upazilas of Naogaon district. The distribution of \%NCA under this pattern in Patnitala and Manda upzilas was $15.6 \%$ for both. Dhamoirhat upazila ranked in $3^{\text {rd }}$ in terms of area coverage (3,000 ha) and \% NCA $(12.93 \%)$ for this pattern. Out of top 11 upazilas of Rajshahi region, the Mustard-Boro- T. Aman cropping pattern existed in top 10 upazilas of Naogaon district covering $88 \%$ (22600 ha) of total Mustard-Boro- T. Aman area in the region indicating that the Naogaon district remained predominated with this pattern. In the countrywide compilation of data it was observed that Mustard-Boro- T. Aman was the $6^{\text {th }}$ dominant cropping pattern in Bangladesh covering 1.85 lac ha $(2.16 \%$ of NCA in the country) with its distribution in 203 upazilas of 51 districts (Nasim et al., 2017).

\section{Fifth dominant cropping pattern}

Fifth dominant cropping pattern Boro-AusT. Aman existed in 17 upazilas of Rajshahi region covering 25,290 ha of land (Table 13). The pattern represented $3.65 \%$ of NCA where Niamatpur upazila of Naogaon district ranked 
Table 10. Distribution of the $2^{\text {nd }}$ dominant Boro-Fallow-Fallow cropping patterns in Rajshahi region, $2014-15$.

\begin{tabular}{|c|c|c|c|c|}
\hline & Upazila & Area (ha) & $\%$ of upazila NCA & $\%$ of the pattern in region \\
\hline 01 & Singra & 7200 & 16.72 & 14.36 \\
\hline 02 & Atrai & 5900 & 25.00 & 11.77 \\
\hline 03 & Naogaon sadar & 5500 & 27.23 & 10.97 \\
\hline 04 & Manda & 4000 & 13.27 & 7.98 \\
\hline 05 & Naldanga & 3500 & 28.57 & 6.98 \\
\hline 06 & Baghmara & 2800 & 9.98 & 5.59 \\
\hline 07 & Porsha & 2500 & 11.63 & 4.99 \\
\hline 08 & Shapahar & 2500 & 12.69 & 4.99 \\
\hline 09 & Gomastapur & 2300 & 9.47 & 4.59 \\
\hline 10 & Mohanpur & 2250 & 19.91 & 4.49 \\
\hline 11 & Raninagar & 2100 & 10.19 & 4.19 \\
\hline 12 & Durgapur & 1500 & 11.45 & 2.99 \\
\hline 13 & Paba & 1100 & 7.41 & 2.19 \\
\hline 14 & Baraigram & 1000 & 4.46 & 1.99 \\
\hline 15 & Gurudaspur & 1000 & 6.62 & 1.99 \\
\hline 16 & Patnitala & 800 & 2.66 & 1.60 \\
\hline 17 & Nachol & 600 & 2.40 & 1.20 \\
\hline 18 & Shibganj & 600 & 2.64 & 1.20 \\
\hline 19 & Niamatpur & 500 & 1.53 & 1.00 \\
\hline 20 & Bagha & 500 & 5.59 & 1.00 \\
\hline 21 & Bholahat & 500 & 5.68 & 1.00 \\
\hline 22 & Tanor & 450 & 2.01 & 0.90 \\
\hline 23 & Puthia & 400 & 3.86 & 0.80 \\
\hline 24 & Dhamoirhat & 300 & 1.29 & 0.60 \\
\hline 25 & Bagatipara & 130 & 2.89 & 0.26 \\
\hline 26 & Godagari & 100 & 0.25 & 0.20 \\
\hline 27 & Chapai sadar & 50 & 0.18 & 0.10 \\
\hline \multirow[t]{2}{*}{28} & Charghat & 50 & 0.61 & 0.10 \\
\hline & Rajshahi region & 50130 & 7.23 & 100.00 \\
\hline
\end{tabular}

the top position in terms of area coverage $(6,000$ ha) and \% NCA (18.4\%). Next to Niamatpur, Gomastapur upazila of Chapainawabganj district occupied the highest area (3,600 ha) and $\%$ of NCA $(14.8 \%)$ for the pattern. Patnitala and Raninagar upazilas of Naogaon district ranked in $3^{\text {rd }}$ position with this pattern in terms of area coverage and \% NCA, respectively. The area coverage as well as of $\% \mathrm{NCA}$ under Boro-Aus- T. Aman cropping system remained lower in Mohanpur upazila of Rajshahi district represented only $0.02 \%$ of total Boro-Aus-T. Aman area in the region.

\section{Crop diversity and cropping intensity}

A wide variation was observed in cropping patterns and crops among the different upazilas of Rajshahi region (Table 14). A total of 172 cropping patterns were recognized in this region. The maximum (36) numbers of cropping patterns were identified in Paba upazila nearly followed by Durgapur (35) and Chapainawabganj upazila (34) while the lower numbers of cropping patterns were found in Charghat (11), which is decreasing followed by Bagha (12) upazila of Rajshahi district. It was evident that Rajshahi region represented a lower rainfall area in the country and thus BMDA established lots of deep tube-wells for irrigation purpose. It has been assumed that lower number of cropping patterns existed in those upazilas where irrigation facilities were limited. The higher number of cropping patterns is generally related to higher level of diversity for cropping pattern. 
Table 11. Distribution of the $3^{\text {rd }}$ dominant Wheat-Fallow-T. Aman cropping patterns in Rajshahi region, $2014-15$.

\begin{tabular}{llccc}
\hline & Upazila & Area (ha) & \% of upazila NCA & \% of the pattern in region \\
\hline 01 & Shapahar & 7500 & 38.07 & 24.89 \\
02 & Godagari & 6000 & 15.17 & 19.91 \\
03 & Nachol & 5000 & 20.00 & 16.59 \\
04 & Gomastapur & 4600 & 18.93 & 15.27 \\
05 & Niamatpur & 2500 & 7.67 & 8.30 \\
06 & Paba & 1100 & 7.41 & 3.65 \\
07 & Bholahat & 1100 & 12.50 & 3.65 \\
08 & Durgapur & 730 & 5.57 & 2.42 \\
09 & Manda & 700 & 2.32 & 2.32 \\
10 & Bagatipara & 300 & 6.67 & 1.00 \\
11 & Dhamoirhat & 200 & 0.86 & 0.66 \\
12 & Raninagar & 150 & 0.73 & 0.50 \\
13 & Porsha & 150 & 0.70 & 0.50 \\
14 & Chapai sadar & 100 & 0.35 & 0.33 \\
\hline & Rajshahi region & 30130 & 4.34 & 100.00 \\
\hline
\end{tabular}

Table 12. Distribution of the $4^{\text {th }}$ dominant Mustard-Boro-T. Aman cropping patterns in Rajshahi region, $2014-15$.

\begin{tabular}{llccc}
\hline & Upazila & Area (ha) & \% of upazila NCA & \% of the pattern in region \\
\hline 01 & Patnitala & 4700 & 15.64 & 18.32 \\
02 & Manda & 4700 & 15.59 & 18.32 \\
03 & Dhamoirhat & 3000 & 12.93 & 11.70 \\
04 & Naogaon sadar & 2500 & 12.38 & 9.75 \\
05 & Niamatpur & 2100 & 6.44 & 8.19 \\
06 & Mohadebpur & 1600 & 5.18 & 6.24 \\
07 & Raninagar & 1400 & 6.80 & 5.46 \\
08 & Shapahar & 1000 & 5.08 & 3.90 \\
09 & Porsha & 1000 & 4.65 & 3.90 \\
10 & Tanor & 850 & 3.79 & 3.31 \\
11 & Badalgachhi & 600 & 3.77 & 2.34 \\
12 & Nachol & 600 & 2.40 & 2.34 \\
13 & Naldanga & 500 & 4.08 & 1.95 \\
14 & Paba & 400 & 2.69 & 1.56 \\
15 & Gomastapur & 400 & 1.65 & 1.56 \\
16 & Shibganj & 200 & 0.88 & 0.78 \\
17 & Bholahat & 100 & 1.14 & 0.39 \\
\hline
\end{tabular}

The highest (0.972) diversity index for cropping pattern was found Bagatipara upazila of Natore district followed by Puthia (0.965) upazila of Rajshahi district while the lowest value of diversity for cropping pattern remained in Raninagar upazila of Naogaon district. Crop diversity index (CDI) ranged from 0.528 in Bagmara upazila to 0.989 in Puthia upazila of Rajshahi district. Next to Puthia, the CDI remained higher (0.979) in Charghat and Durgapur upazila of Rajshahi district indicated that this district represented a diversified cropping zone. The highest cropping intensity (253\%) remained in Badalgachhi upazila of Naogaon district closely followed by Mohanpur (252) upazila of Rajshahi district. Next to Mohanpur upazila, the highest cropping intensity existed in Mohadebpur upazila of Naogaon district while the lowest cropping intensity was found in Bagha (171\%) upazila of Rajshahi district. However, the average cropping intensity in Rajshahi region was $218 \%$. In a simultaneous study, the investigators identified 316 cropping patterns for whole Bangladesh; where the CDI value was 0.952 at national level and the 
Table 13. Distribution of the $5^{\text {th }}$ dominant Boro-Aus-T. Aman cropping patterns in Rajshahi region, $2014-15$.

\begin{tabular}{|c|c|c|c|c|}
\hline & Upazila & Area (ha) & $\%$ of upazila NCA & $\%$ of the pattern in region \\
\hline 01 & Niamatpur & 6000 & 18.40 & 23.72 \\
\hline 02 & Gomastapur & 3600 & 14.81 & 14.23 \\
\hline 03 & Patnitala & 2900 & 9.65 & 11.47 \\
\hline 04 & Singra & 2800 & 6.50 & 11.07 \\
\hline 05 & Raninagar & 2500 & 12.14 & 9.89 \\
\hline 06 & Chapai sadar & 2040 & 7.18 & 8.07 \\
\hline 07 & Shapahar & 1000 & 5.08 & 3.95 \\
\hline 08 & Naogaon sadar & 1000 & 4.95 & 3.95 \\
\hline 09 & Godagari & 900 & 2.28 & 3.56 \\
\hline 10 & Tanor & 700 & 3.13 & 2.77 \\
\hline 11 & Nachol & 700 & 2.80 & 2.77 \\
\hline 12 & Baraigram & 500 & 2.23 & 1.98 \\
\hline 13 & Bholahat & 300 & 3.41 & 1.19 \\
\hline 14 & Natore sadar & 100 & 0.85 & 0.40 \\
\hline 15 & Porsha & 100 & 0.47 & 0.40 \\
\hline 16 & Dhamoirhat & 100 & 0.43 & 0.40 \\
\hline \multirow[t]{2}{*}{17} & Mohanpur & 50 & 0.44 & 0.20 \\
\hline & Rajshahi region & 25290 & 3.65 & 100.00 \\
\hline
\end{tabular}

Table 14. Crop diversity and cropping intensity in Rajshahi region, 2014-15.

\begin{tabular}{|c|c|c|c|c|c|c|}
\hline & Upazila & $\begin{array}{c}\text { No. of identified } \\
\text { pattern }\end{array}$ & No. of crop & $\begin{array}{l}\text { Diversity index for } \\
\text { cropping pattern }\end{array}$ & $\begin{array}{l}\text { Crop diversity } \\
\text { index (CDI) }\end{array}$ & C.I. $(\%)$ \\
\hline 01 & Bholahat & 13 & 09 & 0.923 & 0.962 & 203 \\
\hline 02 & Chapainawabganj & 34 & 19 & 0.862 & 0.942 & 238 \\
\hline 03 & Gomastapur & 29 & 18 & 0.859 & 0.929 & 199 \\
\hline 04 & Nachol & 20 & 11 & 0.876 & 0.943 & 207 \\
\hline 05 & Shibganj & 14 & 13 & 0.869 & 0.925 & 226 \\
\hline 06 & Atrai & 18 & 13 & 0.853 & 0.933 & 190 \\
\hline 07 & Badalgachhi & 19 & 12 & 0.694 & 0.897 & 253 \\
\hline 08 & Dhamoirhat & 21 & 16 & 0.665 & 0.867 & 228 \\
\hline 09 & Manda & 32 & 19 & 0.884 & 0.951 & 223 \\
\hline 10 & Mohadebpur & 23 & 12 & 0.762 & 0.914 & 251 \\
\hline 11 & Naogaon sadar & 26 & 17 & 0.814 & 0.926 & 209 \\
\hline 12 & Niamatpur & 16 & 09 & 0.810 & 0.918 & 224 \\
\hline 13 & Porsha & 16 & 11 & 0.831 & 0.922 & 209 \\
\hline 14 & Patnitala & 15 & 12 & 0.775 & 0.907 & 227 \\
\hline 15 & Raninagar & 18 & 13 & 0.596 & 0.823 & 215 \\
\hline 16 & Shapahar & 15 & 11 & 0.803 & 0.906 & 202 \\
\hline 17 & Bagatipara & 15 & 13 & 0.972 & 0.978 & 172 \\
\hline 18 & Baraigram & 21 & 12 & 0.930 & 0.969 & 232 \\
\hline 19 & Gurudaspur & 29 & 17 & 0.929 & 0.969 & 223 \\
\hline 20 & Lalpur & 20 & 17 & 0.905 & 0.949 & 234 \\
\hline 21 & Natore & 20 & 14 & 0.953 & 0.970 & 215 \\
\hline 22 & Naldanga & 12 & 07 & 0.852 & 0.931 & 188 \\
\hline 23 & Singra & 17 & 13 & 0.749 & 0.881 & 201 \\
\hline 24 & Charghat & 11 & 07 & 0.955 & 0.979 & 240 \\
\hline 25 & Bagha & 12 & 07 & 0.933 & 0.956 & 171 \\
\hline 26 & Bagmara & 22 & 13 & 0.664 & 0.528 & 206 \\
\hline 27 & Durgapur & 35 & 21 & 0.940 & 0.979 & 243 \\
\hline 28 & Godagari & 29 & 18 & 0.859 & 0.934 & 206 \\
\hline 29 & Mohanpur & 15 & 08 & 0.801 & 0.916 & 252 \\
\hline 30 & Paba & 36 & 24 & 0.911 & 0.958 & 242 \\
\hline 31 & Puthia & 21 & 17 & 0.965 & 0.989 & 210 \\
\hline \multirow[t]{2}{*}{32} & Tanor & 16 & 11 & 0.799 & 0.902 & 224 \\
\hline & Rajshahi regeion & 172 & 34 & 0.928 & 0.970 & 218 \\
\hline
\end{tabular}


national average of cropping intensity was $200 \%$ (Nasim et al., 2017). Diversification of crops helps risk reduction as diversification allows a producer to balance low price in one or two crops with reasonable prices in other. (Blade and Slinkard, 2002). The farmers of Kerala diversified their cropping pattern to minimize risk from due to crop failures and price fluctuations (Mahesh, 1999).

\section{CONCLUSION}

The survey results conducted in 32 upazilas of Rajshahi region indicated that the Boro-FallowT. Aman was the most predominant cropping pattern. The number of cropping pattern ranged from 11 to 35 while the cropping intensity values varied from 171 to $253 \%$. The average cropping intensity of the region is $218 \%$ which is higher than the national average. A wide ranged also existed in CDI. Based on the findings following recommendations were made.

- Initiative to be taken to increase productivity of exclusive rice based cropping pattern. As rice is the synonym of the primary food security, the high yielding stress tolerant varieties of rice along with recommended crop management packages to be adopted.

- The upazila s having unique or exceptional cropping patterns with large area coverage might be studied in-depth to extrapolate to similar environments.

- In the single Boro area suitable vegetables might be grown on floating bed system in wet season.

- A large portion of single T. Aman area might be intensified by the inclusion of some stress-tolerant Rabi crops like felon, grasspea etc.

\section{REFERENCES}

Agrawal, D J and A H Kassam. 1976. The importance of multiple cropping in increasing world food supplies. A special publication No. 27, American Society of Agronomy, Madison, Wisconsin. pp. 2-3.
Ali, M Y. 2000. Influence of phosphorus fertilizer and soil moisture regimes on root system development growth dynamics and yield of chickpea. PhD thesis, Bangabandhu Sheikh Mujibur Rahman Agricultural University, Salna, Gazipur 1706.

Blade, S F and A E Slinkard 2002. New Crop Development: The Canadian Experience. In: Trends in New Crops and New Uses. J Janick and A Whipkey (Editors). ASHS Press, Alexandria.

FAO, 1988. Land Resources Appraisal of Bangladesh for Agricultural Development- Report 2: Agroecological regions of Bangladesh. Food and Agriculture Organization of the United Nations, Rome, Italy, 570p.

Gadge, S S. 2003. Influence of changes in cropping pattern on farmers' economic status. Indian J. Ext. Edu. 39(1\&2): 99-101.

Idris, K M, N M Huq. 1987. Soil moisture status of Barind Tract. Soil Resources and Development Institute. Rajshahi 25:21.

Kshirsagar, K G, S Pandey and M R Bellon. 1997. Farmers' perception, varietal characteristics and technology adoption: the case of rainfed village in eastern India. Discussion paper 5/97. Social Sciences Division, International Rice Research Institute. Los Baňos, Laguna, Philippines.

Mahesh, R. 1999. Causes and consequences of change in cropping pattern: A location specific study. Discussion Paper No. 11, Kerala Research Programme on Local Level Development, Centre for Development Studies, Thiruvananthapura.

Mandal, R and M P Bezbaruah. 2013. Diversification of cropping pattern: its determinants and role in flood affected agriculture of Assam Plains. Indian J. Agric. Econ. 68(2): 169-181.

Muttaleb, M A, S M Shahidullah, M Nasim and A Saha. 2017. Cropping systems and land use in Sylhet region. Bangladesh Rice J. 21(2): 273-288.

Nasim, M, S M Shahidullah, A Saha, M A Muttaleb, T L Aditya, M A Ali and M S Kabir. 2017. Distribution of Crops and Cropping Patterns in Bangladesh. Bangladesh Rice J. 21(2): 1-55.

Rashid, M H, A H Khan and M M Alam. 2005. Cropping systems dynamics in greater Khustia. J. Bangladesh Agril. Univ. 3(2): 213-238.

Shahidullah, S M, M Nasim, M K Quais and A Saha. 2017. Diversity of Cropping Systems in Chittagong Region. Bangladesh Rice J. 21(2): 109-122.

Shriar, A J. 2000. Agricultural intensity and its measurement in frontier regions. Agroforestry Systems. 49(3): 301-318. 
Appendix 1. List of cropping patterns in Rajshahi region, 2014-15.

\begin{tabular}{|c|c|c|c|c|c|}
\hline & Cropping pattern & Area (ha) & & Cropping pattern & Area (ha) \\
\hline 001 & Boro-Fallow-T. Aman & 158390 & 065 & Mustard-Boro-Aus-T. Aman & 1700 \\
\hline 002 & Boro-Fallow-Fallow & 50130 & 066 & Mustard-Mungbean-T. Aman & 1700 \\
\hline 003 & Wheat-Fallow-T. Aman & 30130 & 067 & Vegetab-Aus-T. Aman & 1640 \\
\hline 004 & Mustard-Boro-T. Aman & 25650 & 068 & Vegetab-Fallow-T. Aman & 1550 \\
\hline 005 & Boro-Aus-T. Aman & 25290 & 069 & Boro-Jute-T. Aman & 1500 \\
\hline 006 & Fallow-Fallow-T. Aman & 19100 & 070 & Mustard-Aus-Blackgram & 1500 \\
\hline 007 & Wheat-Aus-T. Aman & 16010 & 071 & Vegetab-Aus-Blackgram & 1500 \\
\hline 008 & Potato-Boro-T. Aman & 15610 & 072 & Grasspea-B.Aman & 1380 \\
\hline 009 & Mustard-Boro-Fallow & 13050 & 073 & Maize-Aus-Blackgram & 1300 \\
\hline 010 & Wheat-Mungbean-T. Aman & 12570 & 074 & Potato-Aus-Fallow & 1300 \\
\hline 011 & Wheat-Aus-Blackgram & 12030 & 075 & Boro-Jute-Fallow & 1200 \\
\hline 012 & Boro-B.Aman & 11650 & 076 & Wheat-Vegetab-T. Aman & 1160 \\
\hline 013 & Vegetab-Vegetab-Vegetab & 10715 & 077 & Wheat-B.Aman & 1150 \\
\hline 014 & Wheat-Jute-T. Aman & 10270 & 078 & Onion-Maize-T. Aman & 1050 \\
\hline 015 & Mustard-Boro-Aus & 10200 & 079 & Garlic-Vegetab-Vegetab & 1030 \\
\hline 016 & Boro-Aus-Fallow & 9500 & 080 & Fallo-Fallo-T. Aman(Orchard) & 1000 \\
\hline 017 & Boro-Aus-Blackgram & 8000 & 081 & Maize-Fallow-Fallow & 1000 \\
\hline 018 & Potato-Boro-Aus & 7200 & 082 & Potato-Chilli-Fallow & 980 \\
\hline 019 & Wheat-Aus-Fallow & 7020 & 083 & Onion-Aus-Blackgram & 870 \\
\hline 020 & Wheat-Jute-Fallow & 6720 & 084 & Lentil-Vegetab-Vegetab & 760 \\
\hline 021 & Felon-Fallow-T. Aman & 6400 & 085 & Wht-Sesame-B.gram(Orchard) & 730 \\
\hline 022 & Garlic-B.Aman & 6200 & 086 & Lentil-Aus-T. Aman & 710 \\
\hline 023 & Fallow-Aus-T. Aman & 6120 & 087 & Lentil-Sesame-T. Aman & 710 \\
\hline 024 & Mustard-Fallow-T. Aman & 6000 & 088 & Potato-Maize-Aus-Vegetab & 700 \\
\hline 025 & Potato-Boro-Fallow & 5800 & 089 & Potato-Vegetab-T. Aman & 700 \\
\hline 026 & Potato-Maize-T. Aman & 5350 & 090 & Chilli-Fallow-T. Aman & 670 \\
\hline 027 & Onion-Aus-Fallow & 4450 & 091 & Garlic-Aus-Fallow & 660 \\
\hline 028 & Lentil-Fallow-T. Aman & 4370 & 092 & Boro-Vegetab(Float/Norm) & 630 \\
\hline 029 & Garlic-Jute-Fallow & 4310 & 093 & Lentil-Aus-Fallow & 620 \\
\hline 030 & Potato-Fallow-T. Aman & 4050 & 094 & Chilli-Vegetab-Fallow & 600 \\
\hline 031 & Potato-Maize-Aus & 4000 & 095 & Mungbean-Aus-T. Aman & 600 \\
\hline 032 & Mustard-Aus-T. Aman & 3800 & 096 & Boro-Sesbania-T. Aman & 580 \\
\hline 033 & Maize-Fallow-T. Aman & 3780 & 097 & Wheat-Vegetab-Vegetab & 500 \\
\hline 034 & Wheat-F-T. Aman(Orchard) & 3700 & 098 & Garlic-Aus-T. Aman & 490 \\
\hline 035 & Vegetab-Aus-Fallow & 3680 & 099 & Maize-Aus-T. Aman & 440 \\
\hline 036 & Vegetab-Vegetab-T. Aman & 3550 & 100 & Vegetab-Maize-Fallow & 430 \\
\hline 037 & Vegetab-Vegetab-Fallow & 3500 & 101 & Garlic-Fallow-T. Aman & 410 \\
\hline 038 & Maize-Fallow-Blackgram & 3350 & 102 & Chilli-Aus-Fallow & 400 \\
\hline 039 & Wheat-Maize-T. Aman & 2920 & 103 & Maize-Maize-Fallow & 400 \\
\hline 040 & Lentil-Maize-T. Aman & 2890 & 104 & Onion-Maize-Fallow & 400 \\
\hline 041 & Lentil-Fallow-F (Orchard) & 2780 & 105 & Vegetab-B.Aman & 400 \\
\hline 042 & Onion-Jute-T. Aman & 2750 & 106 & Wheat-Jute-Blackgram & 370 \\
\hline 043 & Wheat-Mungbean-Fallow & 2670 & 107 & Boro-Maize-Blackgram & 350 \\
\hline 044 & Chilli-Aus-T. Aman & 2600 & 108 & Boro-Maize-Fallow & 350 \\
\hline 045 & Potato-Aus-T. Aman & 2600 & 109 & Grasspea-Fallow-T. Aman & 350 \\
\hline 046 & Garlic-Mungbean-T. Aman & 2500 & 110 & Garlic+Muskmelon-B.Aman & 320 \\
\hline 047 & Potato-Jute-Fallow & 2450 & 111 & Garlic+W.Melon-B.Aman & 320 \\
\hline 048 & Lentil-Jute-T. Aman & 2410 & 112 & Lentil-Sesame-Fallow & 300 \\
\hline
\end{tabular}


Appendix 1. Continued.

\begin{tabular}{|c|c|c|c|c|c|}
\hline & Cropping pattern & Area (ha) & & Cropping pattern & Area (ha) \\
\hline 049 & Onion-Vegtab-Vegetab & 2370 & 113 & Maize-Aus-Fallow & 300 \\
\hline 050 & Garlic-Jute-T. Aman & 2320 & 114 & Potato-Maize-Vegetab & 300 \\
\hline 051 & Wheat-Mung-F (Orchard) & 2150 & 115 & Vegetab-Boro-T. Aman & 300 \\
\hline 052 & Chickpea-Fallow-T. Aman & 2110 & 116 & Vegetab-Jute-Fallow & 300 \\
\hline 053 & Vegetab-Onion-Aus & 2100 & 117 & Wheat-Chilli-Fallow & 290 \\
\hline 054 & Wheat-Sesame-T. Aman & 2100 & 118 & Onion-Sesame-Fallow & 280 \\
\hline 055 & Onion-Jute-Fallow & 2010 & 119 & Potato-Maize-Fallow & 270 \\
\hline 056 & Boro-Fallow-Blackgram & 2000 & 120 & Vegetab-Jute-T. Aman & 270 \\
\hline 057 & Maize-B.Aman & 2000 & 121 & Grasspea-Aus-Blackgram & 250 \\
\hline 058 & Potato-Jute-T. Aman & 1980 & 122 & Mustard-Aus-Fallow & 250 \\
\hline 059 & Wheat-Aus-Onion & 1900 & 123 & Chilli-Fallow-Fallow & 240 \\
\hline 060 & Onion-Fallow-T. Aman & 1840 & 124 & Potato-Boro-Aus-T. Aman & 230 \\
\hline 061 & Grasspea-Boro-Aus & 1800 & 125 & Coriander-Fallow-Fallow & 220 \\
\hline 062 & Mustard-Boro-B.Aman & 1800 & 126 & S.Potato-Fallow-Fallow & 220 \\
\hline 063 & Potato-Boro-Jute-T. Aman & 1800 & 127 & Chilli-Vegetab-T. Aman & 210 \\
\hline \multirow[t]{2}{*}{064} & Lentil-Mungbean-T. Aman & 1750 & 128 & Groundnut-Fallow-Fallow & 210 \\
\hline & & & $129-172$ & Other 44 patterns (Table 8) & 3730 \\
\hline
\end{tabular}

